\title{
Satisfying visitors' needs: What to resort to
}

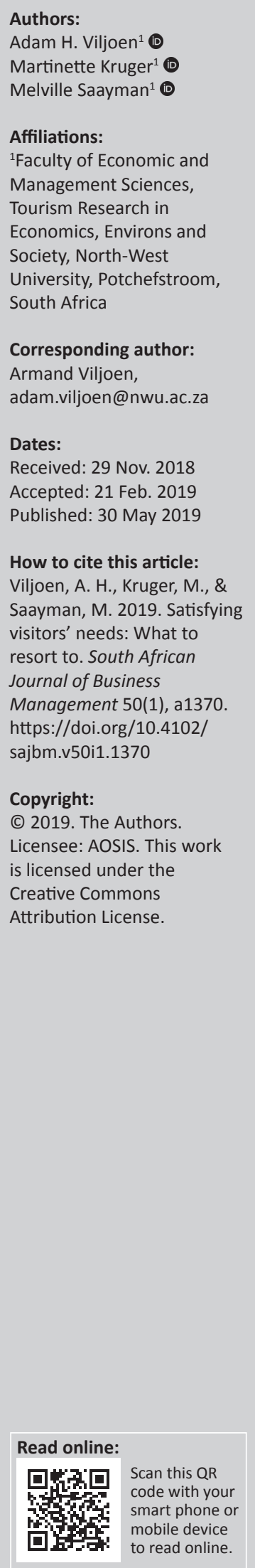

Background: Over centuries resorts across the world have played a pivotal role in tourism and can even be seen as the backbone of tourism as we know and comprehend it today. South Africa is no different, and the country has numerous resorts attracting thousands of visitors annually. Hence, there is strong competition among the different resorts.

Objectives: Based on the above, this research aimed to obtain an understanding of the resort travel market in South Africa by investigating if different resorts attract different types of visitors.

Method: This is an under-researched topic, yet the wide variety of resorts provides ample opportunities for investigation. This article identifies four important travel motives of resort visitors and provides insight into the importance of resort amenities by outlining five essential resort attributes.

Results: This article finds that different resorts attract different markets, which influences the marketing and management opportunities of each resort.

Conclusion: From the results, viable marketing and management recommendations are provided.

Keywords: Resort markets; resort motives; resort attributes; South Africa; factor analysis.

\section{Introduction}

Holiday resorts are typically referred to as a modern occurrence, yet, historically, resort tourism dates back to the Roman Empire, when the 'patricians', the social elite and the political elite, together with the affluent Romans, travelled to the seaside during the summer months (Page \& Connell, 2014). Since the Elizabethan age, 'taking the waters' in spa cities such as Bath was very popular in Britain, where the thermal water was enjoyed recreationally and consumed for the health benefits it was believed to have (British Library Board, 2016). Seaside resorts during the Victorian age catered to the expanding working class with a variety of entertainment offerings (Walton, 2011).

Today resorts are classified in a multitude of ways, ranging from location-/destination-specific resorts to activity-specific resorts. A resort is defined as 'a physical location where a number of tourism-related elements occur to create a cluster of activities, often in attractive locations such as coastal areas, but can be found in mountainous, rural, or city locations' (Page \& Connell, 2014:647). Beaver (2012) states that resorts are contextually vacation areas, places or towns with various leisure facilities, for example, mountain resorts, spa resorts or seaside resorts. Moreover, a resort is also described as a place that attracts a large number of tourists (Cooper, Fletcher, Fyall, Gilbert \& Wanhill, 2008).

The definitions provided do leave some ambiguity concerning the classification of resorts. For example, the location (seaside, mountainous area, inland, rural or city), the ownership (timeshare, holiday, corporate/chain or community), the type of accommodation (chalets, hotels, camping and caravanning, and lodges, to name a few), type of experience (solitude and rejuvenation, family fun and holiday, themed or extreme activities), carrying capacity (e.g. no day visitors allowed) and primary attraction (thermal water, skiing, spa activities, fishing, or beach) would influence the definition of a particular resort. However, distinguishing resorts or the type of resort is important, because it contributes to understanding the market attracted to a specific type of resort. It is generally accepted that consumers/tourists are not homogeneous, and therefore, one may assume that as products and services differ from one resort to the next, the market will adapt accordingly. Gee (2012) classified resorts on the basis of different characteristics such as seasonality, designation, size, location, ownership and others. Table 1 shows the complexities of resorts, and undoubtedly, particular resorts will attract a certain market depending upon the characteristics of the resort. 
TABLE 1: Types of resorts.

\begin{tabular}{|c|c|c|c|c|c|}
\hline Seasonality & Designation & Size & Location & Ownership & Other \\
\hline Year-round & Spa & Mega resorts & Urban & $\begin{array}{l}\text { Public resorts: } \\
\text { - National } \\
\text { - Provincial } \\
\text { - Local }\end{array}$ & All-inclusive \\
\hline Summer & Golf & Boutique resorts & Beach/seaside & Private resorts & Mixed-use \\
\hline Winter & $\begin{array}{l}\text { - Ski } \\
\text { - Guest farm } \\
\text { - Diving } \\
\text { - Fishing } \\
\text { - Marina } \\
\text { - Casino } \\
\text { - Conference } \\
\text { - Campsite } \\
\text { - Eco resort } \\
\text { - Theme park }\end{array}$ & - & $\begin{array}{l}\text { - Lake } \\
\text { - Mountain } \\
\text { - Island } \\
\text { - Desert } \\
\text { - Tropical rain forest } \\
\text { - Farm related }\end{array}$ & $\begin{array}{l}\text { - Membership resorts } \\
\text { - Exclusive resorts }\end{array}$ & $\begin{array}{l}\text { - Themed and/or fantasy } \\
\text { - Floating (cruise ships) }\end{array}$ \\
\hline
\end{tabular}

Source: Adapted from Gee, C. K. (2012). World of resorts: From development to management (3rd edn.). London: Pearson College

According to Walker (2017), the traditional resort model needs to be adapted from single-use resorts to multi-use resorts. This is mainly because of demand changes and modern conceptions of luxury, value for money and convenience. Resorts that are incapable of integrating multiple products/services into the experience face greater challenges in retaining current visitors, while simultaneously increasing spending. In addition, pricequality (luxury, midscale and budget/economy), ratings (depending on country) and geographical setting influence the competitiveness of the resort. Christie-Mill (2008) argues that resorts are mainly visited by families and friends on holiday and individuals travelling for business purposes to conventions and meetings. Moreover, resorts need to gain a competitive advantage by anticipating the demand of consumers in terms of activities and experiences that are not bound by seasonality, and by catering for all ages in an environment that offers village charm with big brands, offering business tourism with family ambience, while being environmentally sustainable, with modern luxuries (Walker, 2017).

The literature furthermore confirms that different tourism products attract different markets. This leads to the questions as to whether this is also true for resorts, and if so, what the characteristics of the market are. To answer these questions, the aim of this research is therefore threefold: firstly, to investigate the profile of visitors to three holiday resorts in South Africa; secondly, to identify the travel motives of the visitors to the resorts and the satisfaction with resort amenities; thirdly, to determine if different resorts attract different markets, and what measures resorts should introduce to satisfy visitors' needs. Gaining a resort-specific competitive advantage is crucial not only to retain current visitors but also to attract new segments in a cost-effective manner in a declining domestic tourism market (Statistics South Africa, 2017). Moreover, little is known about the resort market in South Africa, warranting an investigation to fill the gap in the current literature.

\section{Literature review}

In this section, the South African resort sector will be briefly introduced, followed by a distinction between travel motives and visitor satisfaction with resort amenities.

\section{South African resorts}

The literature and information on resorts in South Africa are extremely limited. Available records indicate that holiday resorts in South Africa date back to the 1840s when Wynberg in the Cape Colony was a popular destination for British officers on leave (South African History Online, 2012). The majority of resorts were owned by the government and managed by municipalities. Towns/municipalities therefore still own public resorts, but many $( \pm 700)$ have fallen into disrepair (Tempelhoff, 2017). During the 1930s, the government decided to start selling the public resorts to private resort-management companies or hotel groups. This resulted in the establishment of private resorts. However, certain private resorts were made even more exclusive by offering membership and time-share options. As illustrated in Figure 1, the resort tourism sector in South Africa is complex, not only in terms of its management and ownership but also on the basis of the wide variety of options available.

Figure 1 illustrates that the type of resort bidirectionally influences resort attributes. The resort attributes influence the resort visitor, and by means of market segmentation, the ideal visitors can be targeted. As was previously mentioned (Table 1), the type of resort depends on certain characteristics such as seasonality, designation, size, location and ownership. Ownership of the resort can be broadly classified into four distinct types, namely public- or government-owned resorts (national, provincial and local government), private resorts, membership resorts and exclusive resorts. Private and membership resorts synonymous with South African holidays include, but are not limited to, the Afrikaanse Taalen Kultuurvereniging (ATKV) resorts, Forever Resorts and Tsogo Sun Resorts. When looking at exclusive (time-share) resorts, hundreds of options are available across the country. Adding to the complexity is the fact that some of these categories are fluid and tend to overlap.

An understanding of the composition of the resort sector provides the opportunity to investigate the demands and needs that visitors have of a certain type of resort. Here resort-specific attributes such as the type of accommodation, facilities, services, activities, attractions and management 
influence the type of visitor. Visitors are also characterised by many attributes such as demographic variables, motives, needs, behaviour, satisfaction and spending. Once demands and needs have been identified, resorts are equipped to deliver satisfactory experiences, which in turn creates a competitive advantage. In addition, resort visitors who are satisfied with the resort experience are likely to return or advocate positive recommendations to friends and family.

Today, there are many different types of resorts in South Africa with high levels of competition between resorts within the same category. Unfortunately, the needs of visitors to resorts in South Africa remain under-researched. Little to no empirical research has focused on this market in the country, with the exception of the well-known casino resort, Sun City, which has gained much scholarly attention (e.g. Botha, Crompton, \& Kim, 1999; Ezeuduji, Lete, Correia, \& Taylor, 2014; Kim, Crompton, \& Kim, 2000). These studies have, however, focused on the competitiveness and brand value of the resort and not the needs of the visitors it attracts. For resorts to survive in an increasingly competitive environment, it is crucial to understand the travel motives of visitors to resorts, as well as to investigate the satisfaction with resort amenities. These matters are covered in the sections below, and the gaps that this research attempts to fill are identified.

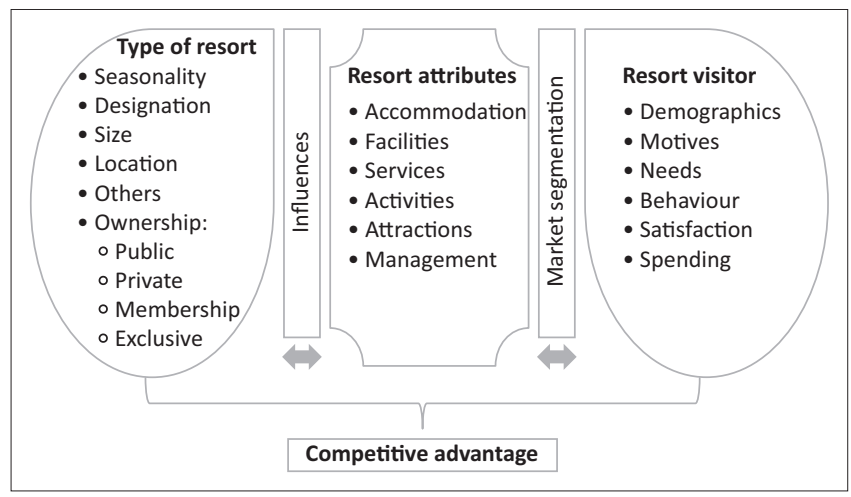

FIGURE 1: Resort tourism in South Africa.

\section{Travel motives in a resort context}

The popularity of identifying motives stems from the need to understand consumer behaviour, resulting in an entire field of study within numerous research disciplines. Motives, similar to desires and needs, account for the actions that consumers take to satisfy particular desires and needs. Travel behaviour and motivation are welldocumented in tourism, hospitality and leisure research by major investigators such as Cohen (1972), Plog (1974), Smith (1977), Crompton (1979), Dann (1981) and Iso-Ahola (1982). The latter investigated the motives of travel and recreation, identifying four motivation dimensions such as (1) escaping personal environment, (2) personal reward seeking, (3) escaping interpersonal environment and (4) interpersonal reward seeking, and also offered a working definition of tourism motivation as the meaningful state of mind that disposes an individual or group of individuals to travel (Iso-Ahola, 1982).

Owing to the abundance of literature, an overwhelming number of motives have been identified. However, certain motives without question reoccur in various contexts. Generic travel motives include novelty, socialisation, prestige/status, rest and relaxation, intellectual enrichment, enhancing kinships, regression/nostalgia and product/ experience attributes (Crompton, 1979; Funk, Toohey, \& Bruun, 2007; Garms, Fredman, \& Mose, 2017; Jang \& Cai, 2002; Kim, Sun, Jogaratnam, \& Oh, 2006; Kruger, Saayman, \& Ellis, 2014; Kruger, Viljoen, \& Saayman, 2013; Mehmetoglu, 2007; Sellick, 2004; Tao, Eagles, \& Smith, 2004; Uysal, McDonald, \& Martin, 1994; Van der Merwe, Slabbert, \& Saayman, 2011). Table 2 indicates resort-specific travel motives, and in recent times, the influence of the product attributes or the experience attributes has become prominent. These attributes are to a certain degree distinctive of the product or the experience. For example, it can be assumed that product/experience attributes of a music festival will

TABLE 2: Previous research on the travel motives to visit resorts.

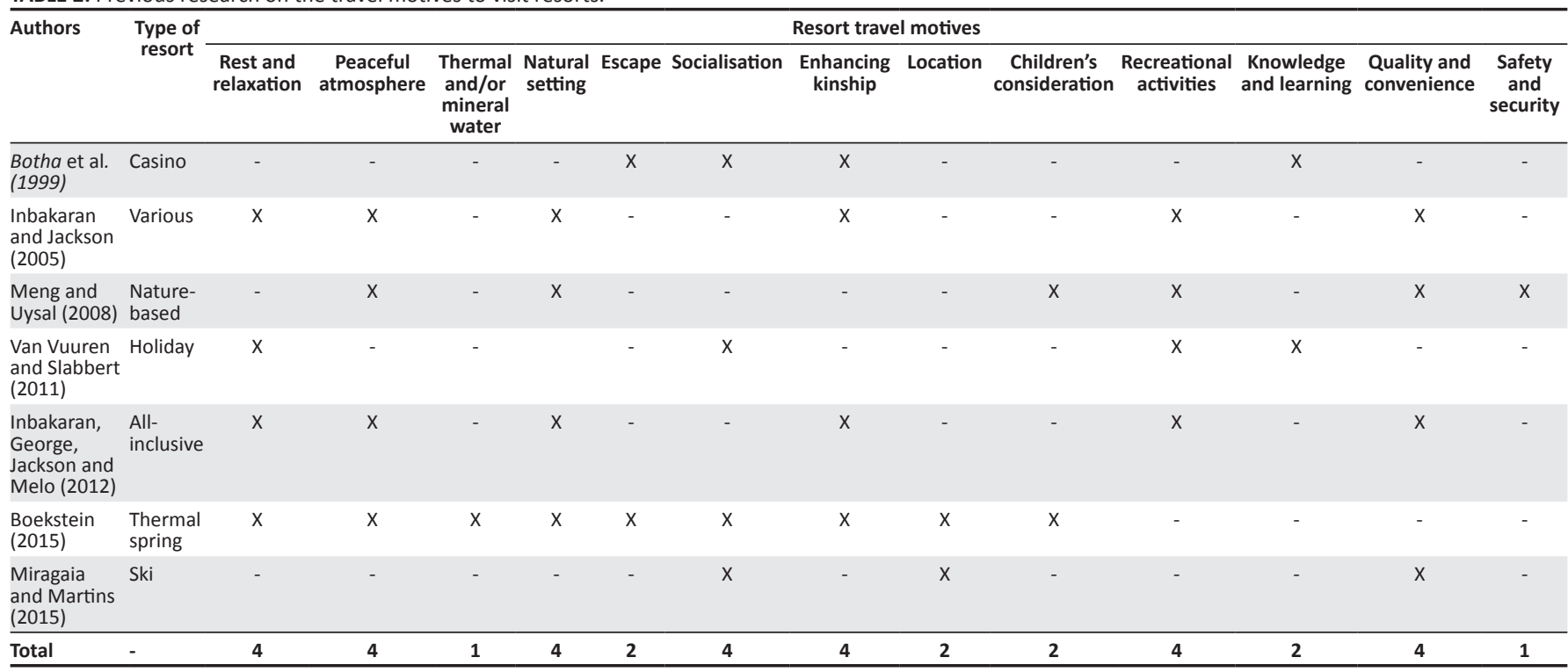


differ from those of a culinary festival, while the generic motives of both festivals might be similar. The greater variety of resort motives is evident and is largely because of the combination of (1) the type of resort and (2) the market attracted to the particular resort.

The resort travel motives are slightly different from the generic motives; nevertheless, certain motives overlap. However, the resort motives are more specific. The most cited motives include a peaceful atmosphere, natural setting and recreational activities. This already indicates that resort visitors are looking for experiences that are in peaceful natural settings, but still offer a variety of activities, where rest and relaxation are promoted, and family time is endorsed. These motives are therefore also closely linked to the resort and amenities on offer. Hence, because the resort motives are more specified, one may assume that resort amenities and attributes shape the type of resort visitor. It is, therefore, necessary to investigate the type of products, services, amenities, attributes and offerings of resorts to comprehend the type of visitor attracted to certain resorts.

\section{Resort amenities and attributes}

Resorts are multifaceted environments where a wide variety of products and services converge, ranging from accommodation options and activity variety to locations. Table 3 summarises the main resort amenities as found in the previous literature.

As indicated in Table 3, resort amenities are in general centred on food and beverage, accommodation and lodging, entertainment, recreational activities, fitness and relaxation (spa), the service quality and natural setting. These indicate to some degree the core aspects that resorts need to offer. However, depending on the type of resort, the amenities and demands will adapt. For example, it is understandable that amenities and demands at a beach resort will differ greatly from those of a ski resort. Therefore, it is vital for resort managers to anticipate and deliver the amenities that will satisfy the needs of the market attracted to a particular resort.
In the literature, this is often referred to as guest and/or visitor satisfaction, which influences the overall competitiveness of any tourism enterprise. However, research indicates that intention to revisit is greatly encouraged (Assaker \& Hallak, 2013; Chi \& Qu, 2008). As many tourism enterprises such as resorts aim to retain visitors on the basis of affordability, loyalty or endorsement, the role of satisfaction is crucial for destination and/or resort management (Žabkar, Brenčič, \& Dmitrović, 2010). One of the core elements of effective destination and/or resort management is tourist satisfaction, which influences the choice of destination/resort and the decision to return (Yoon \& Uysal, 2005). Žabkar et al. (2010) state that tourists' satisfaction is integrally linked to quality. The quality is created during service delivery (staff competence, friendliness, reliability, efficiency and courtesy) and outcomes of service (leisure facilities, amenities, food and beverage, and accommodation). This indicates that resort amenities and the services performed by staff are crucial for retaining current markets and possibly important to new segments.

Owing to the scant availability of empirical research on resort tourism in South Africa, excluding the efforts by Van Vuuren and Slabbert (2011) and Boekstein (2015), this research aims to fill the gap in the literature on the topic.

\section{Methodology}

As this research is quantitative in nature, a structured questionnaire was used to collect the data. This section describes the questionnaire, sampling method, survey, the profile of the respondents, statistical analysis and results.

\section{Case study}

As illustrated in Figure 1, the composition of resorts in South Africa developed over time. Forever Resorts, as it is known today, was established in 2003, but the history of these resorts goes back to the mid-1930s. In 1933, Aventura Resorts was government owned and managed by the Board of Curators for Mineral Springs. In 1975, the management name was changed to the Board of Public Resorts, resulting in a semigovernment company. In 1985, another renaming took place,

TABLE 3: Previous research findings on resort amenities.

\begin{tabular}{|c|c|c|c|c|c|c|c|c|c|c|c|c|c|}
\hline \multirow[t]{2}{*}{ Authors } & \multirow{2}{*}{$\begin{array}{l}\text { Type of } \\
\text { resort }\end{array}$} & \multicolumn{12}{|c|}{ Resort amenities } \\
\hline & & $\begin{array}{l}\text { Accommodation } \\
\text { (infrastructure) }\end{array}$ & $\begin{array}{l}\text { Business } \\
\text { services }\end{array}$ & Entertainment & $\begin{array}{l}\text { Food and } \\
\text { beverages }\end{array}$ & $\begin{array}{l}\text { Size and } \\
\text { accessibility }\end{array}$ & $\begin{array}{l}\text { Brand } \\
\text { affiliation }\end{array}$ & $\begin{array}{l}\text { Recreation, } \\
\text { fitness and } \\
\text { spa }\end{array}$ & $\begin{array}{l}\text { Children } \\
\text { and/or } \\
\text { family } \\
\text { centred }\end{array}$ & $\begin{array}{c}\text { Service } \\
\text { quality } \\
\& \\
\text { staffing }\end{array}$ & $\begin{array}{c}\text { General } \\
\text { management }\end{array}$ & $\begin{array}{l}\text { Natural } \\
\text { setting }\end{array}$ & $\begin{array}{l}\text { Activity } \\
\text { specific }\end{array}$ \\
\hline Botha et al. (1999) & Casino & $x$ & - & $x$ & - & - & - & - & - & - & - & $x$ & - \\
\hline Kim et al. (2000) & Casino & $x$ & - & $x$ & - & - & - & - & - & - & - & $x$ & $x$ \\
\hline $\begin{array}{l}\text { Meng, Tepanon and } \\
\text { Uysal (2008) }\end{array}$ & $\begin{array}{l}\text { Nature- } \\
\text { based }\end{array}$ & $x$ & - & - & $x$ & $x$ & - & $x$ & - & - & $x$ & $x$ & - \\
\hline Stringam (2008) & Time-share & - & - & $x$ & - & $x$ & $x$ & $x$ & $x$ & $x$ & - & - & - \\
\hline Lucas and Tanford (2010) & Casino & $x$ & - & $x$ & $x$ & - & - & - & - & - & - & - & $x$ \\
\hline Brey and Choi (2010) & Water-park & $x$ & $x$ & $x$ & $x$ & - & $x$ & $x$ & $x$ & $x$ & - & $x$ & $x$ \\
\hline $\begin{array}{l}\text { Konu, Laukkanen and } \\
\text { Komppula (2011) }\end{array}$ & Ski & $x$ & - & - & $x$ & - & - & $x$ & - & - & - & - & $x$ \\
\hline Anastassova (2011) & Beach & $x$ & - & $x$ & $x$ & - & - & $x$ & - & $x$ & - & $x$ & - \\
\hline $\begin{array}{l}\text { Van Vuuren and } \\
\text { Slabbert (2011) }\end{array}$ & Holiday & - & - & $x$ & $\mathrm{x}$ & $x$ & - & - & - & $x$ & $x$ & $x$ & - \\
\hline
\end{tabular}


and Overvaal Resorts was established, and four new resorts were acquired. In 1995, the government privatised Aventura Resorts, but by 1999 Protea Hotels was assigned to manage the resorts (Forever Resorts, 2017a).

Since 2003 Forever Resorts has bought Aventura and its eight properties. Forever Resorts operates 20 properties within South Africa, of which nine are classified as resorts, with only one being a beach resort in the Western Cape. The remaining resorts are all located within the Limpopo, Mpumalanga and the Free State provinces (Forever Resorts, 2017b). These eight resorts are all 3-star graded and offer a variety of services and amenities. For the purpose of this research, three Forever Resorts, namely Warmbaths (Limpopo), Loskopdam and Badplaas (Mpumalanga), 'were chosen because of their proximity to South Africa's economic hub, namely Gauteng, as indicated in Figure 2. Moreover, the resorts offer similar facilities and services, and it can, therefore, be assumed that they attract a similar market. These three resorts thus provided the ideal research opportunity to determine the market(s) attracted to the resorts and what distinguishes the resorts from each other.' (Viljoen, Kruger, \& Saayman 2018:25).

\section{Questionnaire}

Questionnaire design and validation is a process recommended in quantitative research. This process is based on steps and guidelines outlined by Hair, Bush and Ortinau (2009) and involves three validation techniques, namely content validity, face validity and construct validity. Content validity is a systematic assessment measuring how well the constructs' measurable components are represented. Face validity is the subjective assessment of the constructs to ensure the constructs are measurable. Construct validity includes identifying the proper independent and dependent variables, as well as the degree to which what is intended to be measured, is measured.

The questionnaire consisted of five sections. Section A captured the socio-demographic details pertaining to gender, age, home language, marital status, travel group size, province of residence, the number of previous visits to the resort, level of education, gross annual income, the frequency of resort facility use and expenditure. Section B captured economic considerations such as travel group composition, number of nights at the resort, media exposure to resort marketing, age exposed to resort, type of accommodation preference and joining the resort group loyalty programme. Section $C$ captured the degree of satisfaction with resort amenities, measuring 32 statements on a 4-point Likert scale of agreement ( 2 = totally disagree to $5=$ totally agree), while $1=$ not applicable. Section D captured the travel motives of visitors to the resort, measured by 41 statements on a 5-point Likert scale of agreement ( $1=$ totally disagree to $5=$ totally Agree $)$.

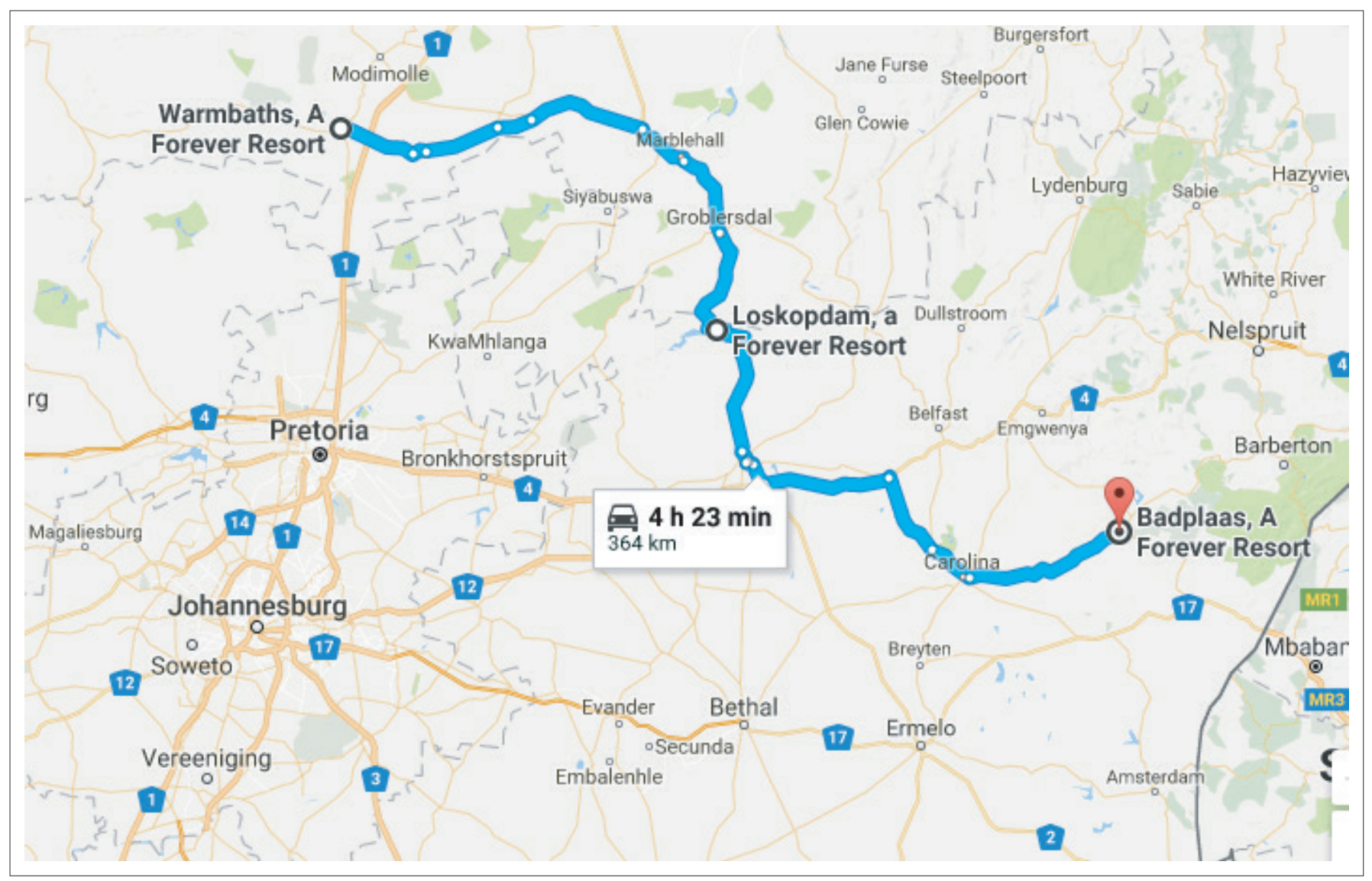

Source: Google Maps. 2017. Forever Resorts, Lodges, Hotels and Retreats, Google Maps, viewed n.d., from https://goo.gl/maps/BUK2hQSpGvMiZ4wH9 FIGURE 2: Location of Forever Resorts included in the research. 
Section E captured the use of spa treatment on a 5-point Likert scale of frequency $(1=$ never to $5=$ every time $)$.

The items were based on research conducted by Brey and Choi (2010), Choi, Letho and Brey (2010), Wen, Letho, Sydnor, and Tang (2014) and Boekstein (2015). The questionnaire was also sent to the resort managers for approval. All the sections, therefore, satisfy the criteria for content validity. In term of face validity, the Statistical Consultation Services advised on the formulation of the statements and the measuring scales used. The construct validity was satisfied by utilising two exploratory principal component factor analyses, respectively, on the 30 resort amenity items and the 16 travel motive items, to explain the variance-covariance structure of a set of variables through a few linear combinations of these variables.

As possible correlations between the different resort amenities and the travel motive factors can be expected, an Oblimin rotation with Kaiser normalisation for both was completed to improve the interpretability of the factor structure. The Kaiser-Meyer-Olkin measure of sampling adequacy was used to determine whether the covariance matrix was suitable for factor analysis. Kaiser's criteria for the extraction of all factors with eigenvalues larger than one were used because they were considered to explain a significant amount of variation in the data. All items with a factor loading greater than 0.4 were considered as contributing to a factor, and all items with loadings less than 0.4 were regarded as not correlating significantly with this factor (Dancey \& Reidy, 2017; Stevens, 2009). Any item that crossloaded onto two factors with a factor loading greater than 0.4 was categorised in the factor where interpretability was best.

To test the reliability of the identified factors, reliability coefficients (Cronbach's alpha) and inter-item correlations were calculated. A reliability coefficient (Cronbach's alpha) was computed for each factor to estimate its internal consistency. All factors with a reliability coefficient above 0.6 were considered acceptable in this study. The average interitem correlations were also computed as another measure of reliability: these, according to Cohen (1988), should lie between 0.15 and 0.55 . Factor scores were calculated as the average of all items contributing to a particular factor to interpret them on the original 5-point Likert scale ( $1=$ totally disagree to $5=$ totally agree).

\section{Sampling method and survey}

Using simple random sampling, 250 questionnaires were distributed at the case study resorts, namely Warmbaths, Loskopdam and Badplaas. 'Over a period of 4 days (08-11 December 2016), three separate teams conducted a visitor survey at the respective resorts...' (Viljoen et al. 2018:25). A total of 90 questionnaires were distributed at Warmbaths, 70 questionnaires at Loskopdam and 90 questionnaires at Badplaas. A total of 233 fully completed questionnaires were included in the analysis (84 from Warmbaths, 64 from Loskopdam and 85 from Badplaas). The authors recognise that the current sample size is not representative, however. As this is only an exploratory investigation, the sample does exceed the recommended pilot study sample size of 50 participants per group/resort (Johanson \& Brooks, 2010). Adult visitors (18> years) were randomly selected as they were sitting down and relaxing in the various areas. To limit bias, a simple random sampling method was employed within a stratified method where the fieldworkers followed specific guidelines as questionnaires were distributed to day and overnight visitors of different, non-homogeneous age and gender groups. The fieldworkers were trained to ensure that they understood the aim of the study and the questionnaire and could brief respondents about the purpose of the research.

\section{Statistical analysis and results}

The 'data from the three resorts were captured and pooled in Microsoft Excel $^{\odot}$ and analysed by using SPSS Version 24 (Statistical Package for the Social Sciences [IBM: SPSS], 2017). The analysis was performed in two stages: two exploratory factor analyses (motives to travel to the resorts and resort amenities) and an analysis of significant differences between the different markets attracted to the respective resorts.' (Viljoen, Kruger, \& Saayman 2018:25).

\section{Results from the exploratory factor analyses}

Two exploratory principal component factor analyses were performed on the 16 motivational items and the 30 resort amenities, respectively, and included in further analysis. The Kaiser-Meyer-Olkin measure of sampling adequacy was 0.90 for the four motivational factors and 0.87 for the five resort amenities, above the commonly recommended value of 0.6. Barlett's test of sphericity was significant in both cases (respectively $x^{2}(120)=1185.53, p<0.05$; and $\left.x^{2}(435)=2663.49, p<0.05\right)$. All items loaded on a factor with a loading greater than 0.4 , and all factors had a reliability coefficient above 0.6 and were thus considered acceptable in this study. The average inter-item correlations were also within the recommended range of 0.15 and 0.55 . The identified factors respectively accounted for $72 \%$ and $69 \%$ of the total variance. As shown in Table 4, the four motivational factors were, in order of importance based on the mean values, resort (3.97), family (3.91), corporate (2.37) and nostalgia (2.31).

Regarding the resort amenities, Table 5 indicates the quality service (4.11) is the factor respondents were most satisfied with. This was followed by activity variety and accessibility (4.04), marketing and hospitality (3.91), maintenance and value (3.89) and campsite management (3.82).

\section{Essential differences between resort markets}

The results of the multivariate analyses in SPSS (IBM, 2017) were used to identify the markets attracted to the three resorts and to indicate any significant differences between 
them $(p<0.05)$. ANOVAs along with effect sizes $(d)$ were used to identify any significant differences between the resorts. Cohen (1988) offers the following guidelines for interpreting effect sizes: small effect: $d=0.2$, medium effect: $d=0.5$, and large effect: $d=0.8$. Chi-square tests with phivalues $(\varphi)$ were further used to identify any further significant differences between the segments based on the categorical variables measured in the questionnaire. Cohen (1988) gives

TABLE 4: Results of the factor analysis on resort motives.

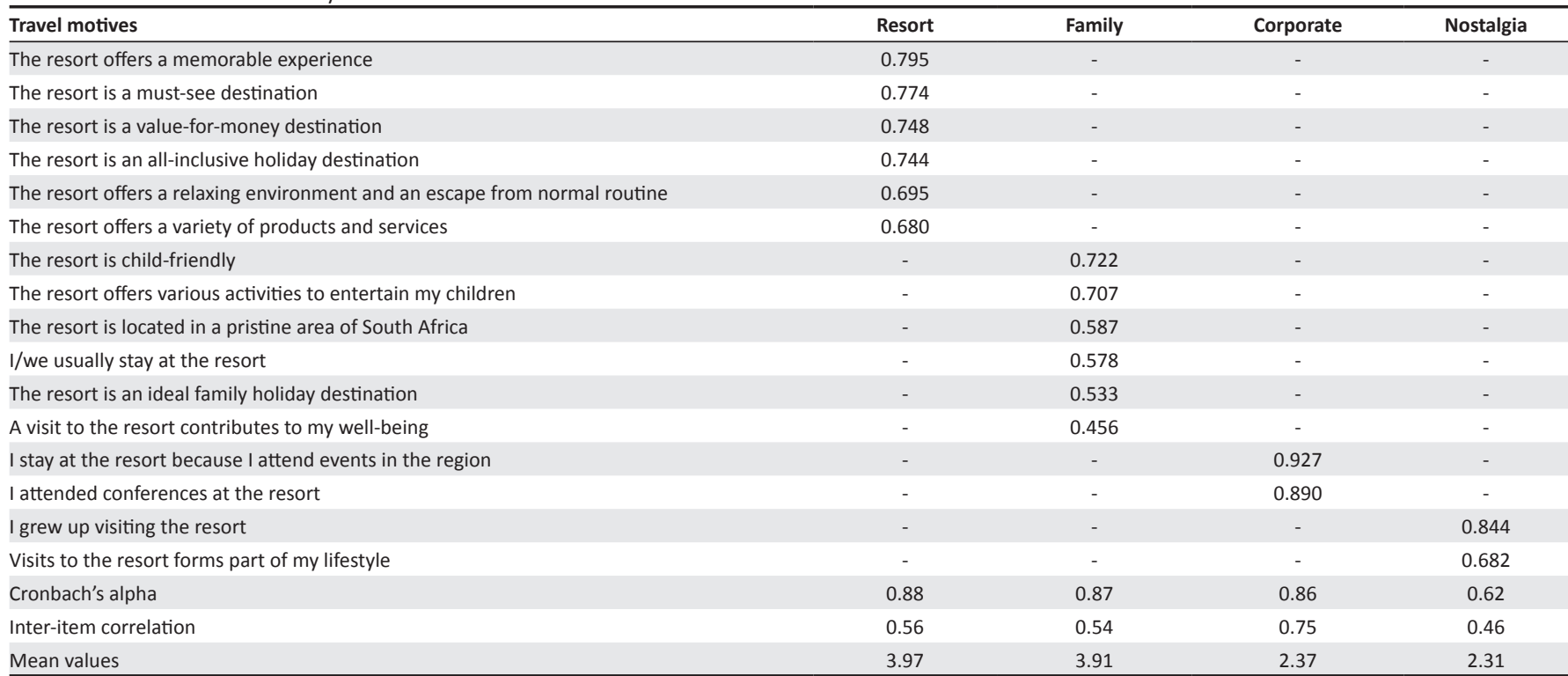

TABLE 5: Results of the factor analysis on resort amenities.

\begin{tabular}{|c|c|c|c|c|c|}
\hline Resort amenities & $\begin{array}{l}\text { Quality } \\
\text { services }\end{array}$ & $\begin{array}{l}\text { Marketing and hospitality } \\
\text { services }\end{array}$ & $\begin{array}{c}\text { Activity variety \& } \\
\text { accessibility }\end{array}$ & $\begin{array}{c}\text { Campsite } \\
\text { management }\end{array}$ & $\begin{array}{l}\text { Maintenance } \\
\text { and value }\end{array}$ \\
\hline Accommodation is clean and tidy & 0.811 & - & - & - & - \\
\hline The physical facilities are visually appealing & 0.745 & - & - & - & - \\
\hline The reception staff are neat and professional & 0.740 & - & - & - & - \\
\hline Quality accommodation is provided & 0.726 & - & - & - & - \\
\hline Bookings are hassle free and easy to do & 0.706 & - & - & - & - \\
\hline Staff, in general, are professional and courteous & 0.620 & - & - & - & - \\
\hline Efficient check-in procedure & 0.587 & - & - & - & - \\
\hline General maintenance is good & 0.552 & - & - & - & - \\
\hline In general, the resort is neat and clean & 0.551 & - & - & - & - \\
\hline The resort offers modern-looking equipment & 0.545 & - & - & - & - \\
\hline Safety at the resort is good & 0.514 & - & - & - & - \\
\hline Visually appealing materials (pamphlets, website) & - & 0.773 & - & - & - \\
\hline Menu variety at restaurant (e.g. vegan/vegetarian, Halaal, Kosher) & - & 0.757 & - & - & - \\
\hline High level of service at restaurants and shops & - & 0.598 & - & - & - \\
\hline Efficient check-out procedure & - & 0.589 & - & - & - \\
\hline Services are delivered promptly and on time & - & 0.582 & - & - & - \\
\hline A variety of facilities are available & - & 0.488 & - & - & - \\
\hline The variety of activities on offer & - & & 0.705 & - & - \\
\hline Directions and signage at the resort are sufficient & - & - & 0.665 & - & - \\
\hline Activities for children are sufficient & - & - & 0.663 & - & - \\
\hline Sufficient parking is provided & - & - & 0.654 & - & - \\
\hline Well-maintained swimming pools & - & - & 0.461 & - & - \\
\hline The variety of accommodation on offer & - & - & 0.452 & - & - \\
\hline Campsites are well serviced & - & - & - & 0.756 & - \\
\hline Camp and caravan sites are well positioned & - & - & - & 0.733 & - \\
\hline Ablution facilities are clean and tidy & - & - & - & 0.637 & \\
\hline In general, the resort is neat and clean & - & - & - & - & 0.667 \\
\hline The resort offers value for money in terms of service & - & - & - & - & 0.652 \\
\hline Inter-item correlation & 0.55 & 0.52 & 0.47 & 0.60 & 0.51 \\
\hline Mean values & 4.11 & 3.91 & 4.04 & 3.82 & 3.89 \\
\hline
\end{tabular}


the following criteria to interpret phi-values: 0.1 for a small effect, 0.3 for a medium effect and 0.5 for a large effect.

Table 6 profiles the markets attracted to each resort based on their socio-demographic and behavioural characteristics, their motives to travel to the respective resorts and their ratings of the resort amenities. There were statistically significant differences $(p \leq 0.05)$ between the markets based on group size, number of previous visits, length of stay (average nights), spending behaviour and spending per person, the travel motives for visiting the resort, family and nostalgia, as well as the resort amenities, quality services, marketing and hospitality services, as well as activity variety and accessibility.

In terms of group size, visitors to Loskopdam had the largest travel groups, an average of 15 people, followed by visitors to Badplaas with nine people. Visitors to Warmbaths travelled in the smallest groups with an average of five people. Visitors to Warmbaths stayed the most nights at the resort: an average of five nights, compared to visitors to Loskopdam, who only stayed an average of three nights. Visitors to Loskopdam were also exposed to resorts at an older age (average of 30 years) compared to the other two resort markets. Visitors to
Warmbaths appeared to be the most loyal resort market and had previously visited the resort an average of five times.

On the other hand, visitors to Loskopdam had visited the resort the fewest times (once before). Loskopdam visitors, however, were the highest spending compared to the other two resorts, making them a lucrative market to retain from an economic point of view. Visitors to Warmbaths had the second highest spending but the highest average spending per person, while visitors to Badplaas had the lowest spending.

Regarding the motives to travel to the resorts, all three markets were motivated by the resorts themselves, followed by family. Visitors to Badplaas appeared to be the only market attracted to the resort for nostalgic reasons, which was also evident in their loyalty and repeat visits to the resort. Visitors to Loskopdam had the lowest mean values across the motives, while visitors to Warmbaths had the highest mean values. In terms of the resort amenities, all three resort markets rated the factor quality services the highest, followed by activity variety and accessibility. Again visitors to Loskopdam rated the resort amenity factors lower compared to the other two resort markets, while visitors to Warmbaths rated the factors the highest.

TABLE 6: Results from the ANOVA and Tukey's post hoc multiple comparisons in the three resort markets.

\begin{tabular}{|c|c|c|c|c|c|c|c|c|}
\hline \multirow[t]{2}{*}{ Variable } & \multicolumn{3}{|c|}{ The resorts } & \multirow[t]{2}{*}{ F-ratio } & \multirow[t]{2}{*}{ Sig.level } & \multicolumn{3}{|c|}{ Effect sizes } \\
\hline & $\begin{array}{l}\text { Badplaas sentimental } \\
\text { resorters }\end{array}$ & $\begin{array}{c}\text { Warmbaths } \\
\text { scrupulous resorters }\end{array}$ & $\begin{array}{l}\text { Loskopdam } \\
\text { stately resorters }\end{array}$ & & & 1 and 2 & 1 and 3 & 2 and 3 \\
\hline \multicolumn{9}{|c|}{ Socio-demographics and behavioural statistics } \\
\hline Number of people in travel group & $9.13^{\mathrm{a}}$ & $5.00^{\mathrm{b}}$ & $14.59^{c}$ & 30.890 & $0.001 *$ & 0.64 & 0.52 & 0.91 \\
\hline Times visited previously & $2.71^{\mathrm{a}}$ & $2.36^{\mathrm{ab}}$ & $1.48^{\mathrm{b}}$ & 5.244 & $0.006 *$ & 0.15 & 0.53 & 0.38 \\
\hline Number of children & 2.42 & 2.49 & 1.84 & 2.598 & 0.079 & 0.06 & 0.52 & 0.59 \\
\hline Age first exposed to resorts & $23.70^{\mathrm{a}}$ & $24.96^{\mathrm{ab}}$ & $29.74^{b}$ & 2.816 & 0.062 & 0.09 & 0.43 & 0.33 \\
\hline \multicolumn{9}{|l|}{ Average spending (ZAR) } \\
\hline Accommodation & 5485.36 & 4732.85 & 6447.92 & 1.505 & 0.225 & 0.15 & 0.14 & 0.25 \\
\hline Food & $1806.14^{\mathrm{a}}$ & $1572.73^{\mathrm{a}}$ & $2590.43^{b}$ & 4.937 & $0.008^{*}$ & 0.14 & 0.36 & 0.46 \\
\hline Beverages & $616.96^{\mathrm{ab}}$ & $968.18^{\mathrm{a}}$ & $385.87^{b}$ & 7.183 & $0.001 *$ & 0.33 & 0.33 & 0.55 \\
\hline Clothes \& footwear & $566.38^{\mathrm{a}}$ & $327.27^{\mathrm{ab}}$ & $153.26^{b}$ & 3.913 & $0.022^{*}$ & 0.22 & 0.38 & 0.32 \\
\hline Transport & $856.07^{a}$ & $819.76^{a}$ & $356.67^{b}$ & 7.337 & $0.001 *$ & 0.04 & 0.60 & 0.60 \\
\hline Activities & $198.21^{\mathrm{a}}$ & $224.77^{a}$ & $21.46^{\mathrm{b}}$ & 9.208 & $0.001 *$ & 0.09 & 0.58 & 0.66 \\
\hline Souvenirs and jewellery & 110.34 & 71.21 & 2.45 & 2.588 & 0.078 & 0.11 & 0.30 & 0.33 \\
\hline Other & $37.50^{\mathrm{ab}}$ & $58.59^{\mathrm{a}}$ & $3.75^{\mathrm{b}}$ & 3.454 & $0.034 *$ & 0.15 & 0.31 & 0.38 \\
\hline Total spending & 6618.67 & 7077.14 & 7670.16 & 0.358 & 0.700 & 0.06 & 0.13 & 0.07 \\
\hline Spending per person & $1127.70^{\mathrm{a}}$ & $2234.26^{b}$ & $800.52^{\mathrm{a}}$ & 6.224 & $0.002 *$ & 0.29 & 0.26 & 0.37 \\
\hline \multicolumn{9}{|l|}{ Travel motives } \\
\hline Resort & $4.04^{\mathrm{a}}$ & $4.06^{\mathrm{a}}$ & $3.68^{b}$ & 3.416 & $0.035 *$ & 0.03 & 0.41 & 0.44 \\
\hline Family & $3.99^{\mathrm{a}}$ & $4.05^{\mathrm{a}}$ & $3.52^{\mathrm{b}}$ & 6.405 & $0.002 *$ & 0.09 & 0.51 & 0.58 \\
\hline Corporate & 2.24 & 2.52 & 2.31 & 0.837 & 0.435 & 0.21 & 0.05 & 0.16 \\
\hline Nostalgia & $3.58^{\mathrm{a}}$ & $3.31^{\mathrm{ab}}$ & $2.78^{b}$ & 5.588 & $0.004^{*}$ & 0.22 & 0.66 & 0.44 \\
\hline \multicolumn{9}{|l|}{ Resort amenities } \\
\hline Quality services & $4.13^{\mathrm{a}}$ & $4.25^{\mathrm{a}}$ & $3.82^{\mathrm{b}}$ & 5.342 & $0.006 *$ & 0.19 & 0.32 & 0.44 \\
\hline Marketing and hospitality services & $3.85^{\mathrm{ab}}$ & $4.09^{\mathrm{a}}$ & $3.67^{\mathrm{b}}$ & 3.449 & $0.034 *$ & 0.29 & 0.17 & 0.39 \\
\hline Activity variety and accessibility & $4.10^{\mathrm{a}}$ & $4.21^{\mathrm{a}}$ & $3.61^{\mathrm{b}}$ & 8.454 & $0.001 *$ & 0.14 & 0.51 & 0.62 \\
\hline
\end{tabular}

Note: Effect sizes: small effect: $d=0.2$; medium effect: $d=0.5$ and large effect: $d=0.8$.

a, Group differs significantly from type (in row) where ${ }^{\mathrm{b}}$ or ${ }^{\mathrm{c}}$ or ${ }^{\mathrm{d}}$ is indicated.

*, Statistically significant difference: $p \leq 0.05$. 
The cross-tabulation and chi-square tests revealed a statistically significant difference between the three segments when it came to home language ( $p=0.001 ; \varphi=0.346)$ and province of origin $(p=0.001 ; \varphi=0.494)$. Visitors to Badplaas were mainly English-speaking (49\%), while visitors to Warmbaths were mostly Afrikaans-speaking (39\%) or spoke another language (mostly African languages) (35\%). A significant portion of visitors to Loskopdam spoke other African languages (55\%), while 38\% spoke English. Regarding province of origin, the majority of the visitors to both Badplaas and Warmbaths (67\% and $41 \%$, respectively) had travelled from Gauteng. A large percentage of visitors to Warmbaths had also travelled from Mpumalanga (38\%). While 38\% of visitors to Loskopdam had also travelled from Gauteng, the majority of visitors were from Mpumalanga (48\%).

Based on the characteristics of each market, a 3-S typology of resort visitors is proposed. As visitors to Badplaas were attracted to the resort because of nostalgic reasons and because they were loyal to the resort, these visitors appeared to be reminiscent and were therefore labelled sentimental resorters. Visitors to Warmbaths appeared to be all-inclusive and dependable resort visitors with their longer length of stay, higher spending per person and higher ratings of the motives and resort amenity factors. Therefore, these visitors were labelled the scrupulous resorters. Finally, the market to Loskopdam appeared to be mainly first-time visitors who travelled in large groups, which could be an indication of a significant percentage of these visitors being day visitors to the resort. This market, however, was the highest spenders, and they were therefore labelled the stately resorters.

\section{Finding and implications}

The goal of this article was to investigate whether different resorts attracted different market segments, based on the travel motives of visitors and resort-specific attributes. This research emphasises the importance of customised resort marketing strategies. These strategies should be based on the needs of the market, as well as highlight the distinct features and attributes of each resort. Therefore, this article identified the following findings and implications to answer the three key questions that this research set out to answer.

\section{Why do tourists visit a resort?}

The results confirmed that the type of resort greatly influences the combination of motives. Four distinct travel motives were revealed, while the combination of these motives had not been identified prior to this investigation (see Table 2). The identified travel motives were resort, family, corporate and nostalgia. In terms of the resort motive, a memorable experience was considered highly important, followed by the destination being labelled a must-see destination, regarded as value for money and considered an all-inclusive holiday destination. Therefore, this motive advocated inclusivity with regard to resort visits and is an important finding to marketers, implying the promotion of what the resort offers.
In terms of the family motive, child safety and a variety of children's activities were regarded as crucial. This indicates that families travelling to resorts are concerned with the safety of the children, as well as a variety of activities during the stay. The most important travel motives were resort and family, indicating that visitors to resorts are aware of the experience offered by the resort and the value for money the resort should offer. This is reasonable, as resorts attract families, therefore ensuring a budget-friendly all-inclusive family holiday as a selling point that many resorts use. The difficulty of creating an outstanding experience that can cater for family needs at a reasonable price is the challenge that resort managers face, especially as the domestic travel market is declining (Stats SA, 2017). Therefore, creating value is essential, and resorts that are more inclined to package deals that include the combination of accommodation options, vouchers for dining out, activities for children and reduced entry fees for children could possibly gain an advantage by increasing visitor numbers, or at the very least, they can maintain the current market size.

The corporate motive emphasised the important role of events and conferences or meetings to the resort sector. This implies that resorts have the ability to attract visitors who are more concerned with business activities. Alternatively, corporate retreats are a valuable alternative to year-end functions, to which employees might bring along families. Again, this is a useful finding, as it shows that corporate events can be used to attract visitors to the resorts during off-seasons when it is generally quiet.

Finally, the nostalgia motive pairs well with the family motive, because for sentimental reasons, visiting the resort of one's childhood encourages a sense of nostalgia. In addition, nostalgia contributes to loyalty and return visitation, as is evident from research conducted in national parks in South Africa (Kruger \& Saayman, 2010; Kruger, Saayman, \& Hermann, 2014; Van Der Merwe \& Saayman, 2008). This indicates that families are probably returning to the same resorts the parents were exposed to as children. The effect of nostalgia on destination choice and revisit intention can therefore be an attractive marketing strategy. The nostalgia motive also supports the notion of loyalty, and this is a very important motive from a marketing point of view, because one does not have to convince these visitors to visit the resorts.

\section{How do tourists rate resort amenities and attributes?}

Similar to the motives, the results confirm that the combination of resort amenities and attributes is determined by the type of resort. The five amenities and attributes were, in order of importance, quality services, activity variety and accessibility, marketing and hospitality services, maintenance and value and campsite management. Compared to the findings from previous research (Table 3), some similarities exist.

Quality service was also identified by Stringam (2008), Brey and Choi (2010), Anastassova (2011) and Van Vuuren and 
Slabbert (2011), while Kim et al. (2000), Lucas and Tanford (2010), Brey and Choi (2010) and Konu et al. (2011) identified factors similar to activity. Accessibility was identified by Meng, Tepanon and Uysal (2006), Stringam (2008), and Van Vuuren and Slabbert (2011). However, similar attributes were identified as factors on their own and not in combination with others, as is the case in this research.

As quality services was the resort attribute with which respondents were the most satisfied, the quality, cleanliness and tidiness of accommodation, coupled with visually appealing facilities and neat and professional staff, are important elements to consider. This implies that resorts have to pay particular attention to accommodation infrastructure, as well as to overall resort facilities. Resort staff should also be trained to deliver professional services, necessitating the role of staff management and especially the function of the human resources department.

In terms of activity variety and accessibility, the resort should offer a wide-ranging set of activities to resort visitors. Here activities for children are also important, again indicating that resorts are family-centred destinations. Furthermore, resorts should especially ensure that directions to and signage at the resort are clear, legible and correct in providing instructions or indicating routes. To enhance the factor marketing and hospitality services, resort marketers should ensure that visually appealing marketing materials such as pamphlets are used, as well as online access via the resort website. The resort website should also be user-friendly. Respondents also indicated that menu variety at restaurants was important, prompting the conclusion that the resort visitors are conscious of what they eat, and therefore, resorts should cater to varied dietary requirements.

Maintenance and value are also considered important to resort, visitors, especially in terms of the cleanliness of the resort. Moreover, the resort should offer value for money in terms of service delivery and price. Although the difference between service delivery and price may not be great, it does indicate that resort visitors are more concerned with service delivery than with price. This indicates that resorts should offer excellent service throughout the entire resort experience lifecycle. Excellent service from booking, checking in, staying at and checking out of the resort is crucial.

Finally, coupled with quality services and the importance of accommodation, resort managers should be aware of the importance of campsite management. This factor was rated the lowest by respondents, indicating room for improvement. Campsites need to be serviced regularly, and special attention should be given to the cleanliness of ablution facilities for campers and caravan users. The position of the campsite is also important, indicating that when future developments are planned, resorts should keep the layout in mind.

The quality services and activity variety and accessibility were considered the most important resort attributes. These factors show that resort visitors require quality accommodation offerings in facilities that are appealing and provide professional services from staff. This implies that resort management should pay particular attention to maintenance and staff training, as well as offer a variety of accommodation options. In addition, the variety of activities should be a focal point, especially during school holidays, when families tend to travel. Resorts could offer holiday programmes that entertain the children while the parents are relaxing. This could include a multitude of activities, ranging from arts and culture projects to sport and recreation-driven projects. It might be wise for resorts to offer holiday internships to university students to act as 'camp counsellors' over the holiday.

\section{Do different resorts attract different market segment(s)?}

The results confirm that although similarities existed, each resort attracted a different market. Based on the characteristics of the markets, segments of visitors based on the resort visited were identified. This typology could become the slogan and strategy for marketing the resorts. Badplaas visitors were considered sentimental, Warm baths visitors were scrupulous, while Loskopdam visitors were stately. Slogan examples could include the following: (1) 'Forever Resort Warmbaths: Forever Value/s', (2) 'Forever Resort Badplaas: Forever Timeless' and (3) 'Forever Resort Loskopdam: Forever Y/ours'.

The results indicated that the sentimental resorters were especially motivated because of the nostalgia of visiting a particular resort. This is a reoccurring motive in tourism literature and a crucial element of a resort's success because of loyalty. Particular attention should be paid when combining the 'old' with the 'new', ensuring that facilities and services are innovative, yet revive the charm of days gone by. Scrupulous resorters are reliable and all-inclusive experience seekers. Packages could be a good way to encourage re-visits as they tend to be high spenders and overnight (stay) the longest. The stately resorters are the highest spenders and tend to travel in large groups, mainly for the first time. Exposing them to all the resort offers may encourage repeat visits and increase the length of stay.

As the resorts differ with respect to the type of market they attract, marketing strategies should be based on the needs of a particular market. For example, the sentimental resorters are aware of the nostalgic experience at the resort, presumably from previous visits, and therefore, Badplaas should try and incorporate traditional experiences in the modern setting. Identifying the experiences is beyond the scope of this study, but this finding emphasises the need for continuous research of this nature, as well as for including more resorts.

The scrupulous resorters at Warmbaths are the all-inclusive experience seekers, and here package deals can really be of benefit. The resort should try and offer family packages that could consist of three-, five- or seven-night accommodation (prices depending on accommodation option) for families 
consisting of two adults and two children (additional children pay extra). Children under the age of 10 could stay free, depending on the number of nights, and restaurant/kiosk vouchers could be included. Along with these, a variety of activities and children's programmes can be included for free ( $<10$ years), and a day/week pass can be provided for older children.

Finally, the stately resorters at Loskopdam are a prime market to consider and should be encouraged to overnight for longer periods of time. Here a mixed approach from the other two resorts may influence visitors to stay longer, thus increasing the already high spending of this segment.

\section{Conclusion}

'This exploratory research is, as far as the authors know, one of the few to analyse the market of resorts in South Africa. The study contributes to the field of research in three ways. The results firstly identified motives [of] visitors to three separate resorts and emphasised that the combination and strength of the factors identified were [largely] determined by the type and nature of the resort and the market it attracted. Secondly, the research identified the resort amenities that respondents were satisfied with at the resorts. Again the results highlighted that the type of resort and market it attracted influenced the rating and satisfaction of the resort amenities.' (Viljoen et al. 2018:25).

'Finally, the results confirmed that although resorts may appear similar in terms of their amenities, they attract different markets that differ [in terms of] their sociodemographics, motives and rating of the resort amenities. Based on the heterogeneity of the resort markets, a typology of resort visitors was created that is descriptive of the needs of the market attracted to the respective resorts. This typology should be used as the basis for the marketing strategies and branding of the resorts and is invaluable in gaining a competitive advantage' (Viljoen et al. 2018:25). However, more research is required to validate and expand on the typology of visitors attracted to resorts in South Africa.

Concerning the contribution of this research, the use of travel motives to tourism destinations and products have been well documented, similarly the use of particular destination and product-specific attributes. This is, however, the first instance where both these determinants have been used to segment visitors to resorts in South Africa. The research, therefore, reaffirms the importance of managing visitor experiences, especially regarding destinations which cater to a variety of needs and preferences, ranging from family to corporate clients, as well as catering for resort-specific amenities and nostalgia. The segmentation bases might also be employed in segmenting other destinations or products such as parks, zoos and aquariums, and all other multi-purpose destinations. This research, therefore, contributes to the application of multi-segmentation approaches with the resort and broader tourism literature.

\section{Acknowledgements}

The authors would like to thank the National Research Foundation, the management of Forever Resorts, the fieldworkers and the respondents for the input in delivering this publication.

This work is based on the research supported by the National Research Foundation (NRF) any opinion, finding and conclusion or recommendation expressed in this material is that of the authors and the NRF does not accept any liability in this regard. The management of Forever Resorts, the field workers and the respondents for the input in delivering this publication.

\section{Competing interests}

The authors declare that they have no financial or personal relationships that may have inappropriately influenced them in writing this article.

\section{Author's contributions}

A.H.V. was responsible for the overall layout of the article, literature review and discussion. M.K. analysed the data and was the primary contributor to the methodology. M.S. contributed in terms of the findings and implications.

Sadly Melville Saayman passed away while this publication was still in press, we are grateful for his mentorship and continued support.

\section{References}

Anastassova, L. (2011). Tourist loyalty and destination brand image perception: The case of Sunny beach resort, Bulgaria. European Journal of Tourism Research, 4(2), 191-209. https://doi.org/10.1177/0047287513478497

Assaker, G., \& Hallak, R. (2013). Moderating effects of tourists' novelty-seeking tendencies on destination image, visitor satisfaction, and short- and long-term revisit intentions. Journal of Travel Research, 52(5), 600-613.

Beaver, A. (2012). A dictionary of tourism and travel. Oxford: Oxford University Press.

Boekstein, M. S. (2015). Health and the motivation to visit thermal spring resorts in the Western Cape, South Africa: Tourism. African Journal for Physical Health Education, Recreation and Dance, 21(1/2), 415-425.

Botha, C., Crompton, J. L., \& Kim, S. S. (1999). Developing a revised competitive position for Sun/Lost City, South Africa. Journal of Travel Research, 37(4), 341-352. https://doi.org/10.1177/004728759903700404

Brey, E. T., \& Choi, H. G. (2010). Standard resort hospitality elements: A performance and impact analysis. Journal of Tourism Insights, 1(1), 21-35.

British Library Board. (2016). Taking the waters. Retrieved from http://www.bl.uk/ learning/langlit/texts/waters/takingthewaters.html

Chi, C. G. Q., \& Qu, H. (2008). Examining the structural relationships of destination image, tourist satisfaction and destination loyalty: An integrated approach. Tourism Management, 29(4), 624-636. https://doi.org/10.1016/j.tourman.2007.06.007

Choi, H. Y., Lehto, X., \& Brey, E. T. (2010). Investigating resort loyalty: Impacts of the family life cycle. Journal of Hospitality Marketing \& Management, 20(1), 121-141. https://doi.org/10.1080/19368623.2011.530185

Cohen, E. (1972). Toward a sociology of international tourism. Social Research, 39(1), 164-182.

Cohen, J. (1988). Statistical power analyses for the social sciences. Hillsdale: Lawrence Erlbauni Associates.

Cooper, C., Fletcher, J., Fyall, A., Gilbert, D., \& Wanhill, S. (2008). Tourism principles and practices (4th edn.). Harlow: Pearson Education.

Christie-Mill, R. C. (2008). The inter-relationships between leisure, recreation, tourism, and hospitality. In R. C. Wood \& B. Brotherton (Eds.), The SAGE handbook of hospitality management (pp. 90-106). London: Sage. http://dx.doi.org/ 10.4135/9781849200417.n4

Crompton, J. L. (1979). Motivations for pleasure vacation. Annals of Tourism Research, 6(4), 408-424. https://doi.org/10.1016/0160-7383(79)90004-5 
Dancey, C. P., \& Reidy, J. (2017). Statistics without maths for psychology (7th edn.). Upper Saddle River, NJ: Pearson.

Dann, G. M. (1981). Tourist motivation and appraisal. Annals of Tourism Research, 8(2), 187-219. https://doi.org/10.1016/0160-7383(81)90082-7

Ezeuduji, I. O., Lete, P. M., Correia, M., \& Taylor, A. M. (2014). Competitive advantage for brand positioning: The case of Sun City in South Africa. Tourism Review International 17(4), 299-306. https://doi.org/10.3727/154427214X13910101597283

Forever Resorts. (2017a). Where do we come from? Retrieved from http://www.foreversa. co.za/index.php/about-forever-resorts/forever-resorts-themadadprocess

Forever Resorts. (2017b). Our properties. Retrieved from http://www.foreversa.co.za/ index.php/our-properties\#

Funk, D. C., Toohey, K., \& Bruun, T. (2007). International sport event participation: Prior sport involvement; destination image; and travel motives. European Sport Management Quarterly, 7(3), 227-248. https://doi.org/10.1080/ 16184740701511011

Garms, M., Fredman, P., \& Mose, I. (2017). Travel motives of German tourists in the Scandinavian mountains: The case of Fulufiället National Park. Scandinavian Journal of Hospitality and Tourism, 17(3), 239-258. https://doi.org/10.1080/1502 2250.2016.1176598

Gee, C. K. (2012). World of resorts: From development to management (3rd edn.) London: Pearson College.

Google Maps. 2017. Forever Resorts, Lodges, Hotels and Retreats, Google Maps, viewed n.d., from https://goo.gl/maps/BUK2hQSpGvMiZ4wH9

Hair, J. F., Bush, R. P., \& Ortinau, D. J. (2009). Marketing research in a digital information environment (4th edn.). Boston, MA: McGraw-Hill Higher Education.

IBM Corp. Released 2016. IBM SPSS Statistics for Windows, Version 24.0. Armonk, NY: IBM Corp.

Inbakaran, R., George, B., Jackson, M., \& Melo, F. R. E. (2012). Identifying resort tourism market segments based on visitor demographics: A study. Academica Turistica-Tourism and Innovation Journal, 5(2), 85-94.

Inbakaran, R., \& Jackson, M. (2005). Understanding resort visitors through segmentation. Tourism and Hospitality Research, 6(1), 53-71. https://doi. org/10.1057/palgrave.thr.6040044

Iso-Ahola, S. E. (1982). Toward a social psychological theory of tourism motivation A rejoinder. Annals of Tourism Research, 9(2), 256-262. https://doi.org/ 10.1016/0160-7383(82)90049-4

Jang, S., \& Cai, L. A. (2002). Travel motivations and destination choice: A study of British outbound market. Journal of Travel \& Tourism Marketing, 13(3), 111-133. https://doi.org/10.1300/J073v13n03_06

Johanson, G. A., \& Brooks, G. P. (2010). Initial scale development: Sample size for pilot studies. Educational and Psychological Measurement, 70(3), 394-400. https:// doi.org/10.1177/0013164409355692

Kim, K., Sun, J., Jogaratnam, G., \& Oh, I. K. (2006). Market segmentation by activity preferences: Validation of cultural festival participants. Event Management, 10(4) 221-229. https://doi.org/10.3727/152599507783948666

Kim, S. S., Crompton, J. L., \& Botha, C. (2000). Responding to competition: A strategy for Sun/Lost City, South Africa. Tourism Management, 21(1), 33-41. https://doi. org/10.1016/S0261-5177(99)00094-1

Konu, H., Laukkanen, T., \& Komppula, R. (2011). Using ski destination choice criteria to segment Finnish ski resort customers. Tourism Management, 32(5), 1096-1105. https://doi.org/10.1016/j.tourman.2010.09.010

Kruger, M., \& Saayman, M. (2010). Travel motivation of tourists to Kruger and Tsitsikamma National Parks: A comparative study. South African Journal of Wildlife Research, 4O(1), 93-102. https://doi.org/10.3957/056.040.0106

Kruger, M., Saayman, M., \& Hermann, U.P. (2014). First-time versus repeat visitors at the Kruger National Park. Acta Commercii, 14(1), 1-9. https://doi.org/10.4102/ ac.v14i1.220

Kruger, M., Viljoen, A., \& Saayman, M. (2013). Who pays to view wildflowers in South Africa? Journal of Ecotourism, 12(3), 146-164. https://doi.org/10.1080/14724049 .2013 .871286

Kruger, S., Saayman, M., \& Ellis, S. (2014). The influence of travel motives on visito happiness attending a wedding expo. Journal of Travel \& Tourism Marketing, 31(5), 649-665. https://doi.org/10.1080/10548408.2014.883955

Lucas, A. F., \& Tanford, S., (2010). Evaluating the impact of a new resort amenity on gaming business volumes. UNLV Gaming Research \& Review Journal, 14(2) $1-14$.

Mehmetoglu, M. (2007). Typologising nature-based tourists by activity - Theoretical and practical implications. Tourism Management, 28(3), 651-660. https://doi. org/10.1016/j.tourman.2006.02.006
Meng, F., \& Uysal, M. (2008). Effects of gender differences on perceptions of destination attributes, motivations, and travel values: An examination of a naturebased resort destination. Journal of Sustainable Tourism, 16(4), 445-466. https:// doi.org/10.1080/09669580802154231

Meng, F., Tepanon, Y., \& Uysal, M. (2008). Measuring tourist satisfaction by attribute and motivation: The case of a nature-based resort. Journal of vacation marketing 14(1), 41-56. https://doi.org/10.1177/1356766707084218

Miragaia, D. A. M., \& Martins, M. A. B. (2015). Mix between satisfaction and attributes destination choice: A segmentation criterion to understand the ski resorts consumers. International Journal of Tourism Research, 17(4), 313-324. https:// doi.org/10.1002/jtr.2009

Page, S. J., \& Connell, J. (2014). Tourism: A modern synthesis (4th edn.). Andover: Cengage Learning.

Plog, S. C. (1974). Why destination areas rise and fall in popularity. Cornell Hospitality Quarterly, 14(4), 55-58. https://doi.org/10.1177/001088047401400409

Sellick, M. C. (2004). Discovery, connection, nostalgia: Key travel motives within the senior market. Journal of Travel \& Tourism Marketing, 17(1), 55-71. https://doi. org/10.1300/J073v17n01_04

Sim, J., \& Lewis, M. (2012). The size of a pilot study for a clinical trial should be calculated in relation to considerations of precision and efficiency. Journal of Clinical Epidemiology, 65(3), 301-308. https://doi.org/10.1016/j.jclinepi.2011.07.011

Smith, V. L. (1977). Hosts and guests: The anthropology of tourism. Philadelphia, PA: University of Pennsylvania Press.

South African History Online. (2012). Wynberg. Retrieved from http://www.sahistory. org.za/places/wynberg

Statistics South Africa. (2017). Domestic tourism survey 2015. Retrieved from http:// www.statssa.gov.za/publications/P03521/P035212015.pdf

Stevens, J. (2009). Applied multivariate statistics for the social sciences (5th edn.). New York: Routledge.

Stringam, B. B. (2008). A comparison of vacation owner amenities with hotel and resort hotel amenities. Journal of Retail and Leisure Property, 7(1), 186-203. https://doi.org/10.1057/rlp.2008.10

Tao, C. H., Eagles, P. F., \& Smith, S. L. (2004). Profiling Taiwanese ecotourists using a self-definition approach. Journal of Sustainable Tourism, 12(2), 149-168.

Tempelhoff, E. (2017). 700 vakansieoorde in SA is vervalle. Retrieved from http:// www.netwerk24.com/Nuus/Algemeen/700-vakansieoorde-in-sa-is-vervalle20170314

Uysal, M., McDonald, C. D., \& Martin, B. S. (1994). Australian visitors to US national parks and natural areas. International Journal of Contemporary Hospitality Management, 6(3), 18-24. https://doi.org/10.1108/09596119410059209

Van der Merwe, P., \& Saayman, M. (2008). Travel motivations of tourists visiting Kruger National Park. Koedoe, 50(1), 154-159. https://doi.org/10.4102/koedoe. v50i1.140

Van der Merwe, P., Slabbert, E., \& Saayman, M. (2011)I. Travel motivations of tourists to selected marine destinations. International Journal of Tourism Research, 13(5) 457-467. https://doi.org/10.1002/jtr.820

Van Vuuren, C., \& Slabbert, E. (2011). Travel behaviour of tourists to a South African holiday resort: Tourism. African Journal for Physical Health Education, Recreation and Dance, 17(1), 694-707.

Viljoen, A., Kruger, M., \& Saayman, M. (2018). The INC 2018: Tourism, Hospitality \& Events in a Changing World. Conference proceedings held at the University of Derby, Buxton, 26-28 June 2018. Buxton: University of Dereby, viewed n.d., from https:// theconference2018.files.wordpress.com/2018/07/the-inc-2018-proceedings1.pdf?

Walker, A. (2017). Developing successful resorts. Retrieved from http://www.colliers. $\mathrm{com} /$-/media/files/emea/uk/research/destination-consulting/developing successful-resorts.pdf

Walton, J. (2011). The Victorian seaside. Retrieved from http://www.bbc.co.uk/ history/british/victorians/seaside_01.shtml

Wen, X., Lehto, X. Y., Sydnor, S. B., \& Tang, C. H. (2014). Investigating resort attribute preferences of Chinese consumers: A study of the post-1980s and their predecessors. Journal of China Tourism Research, 10(4), 448-474. https://doi.org /10.1080/19388160.2014.959629

Yoon, Y., \& Uysal, M. (2005). An examination of the effects of motivation and satisfaction on destination loyalty: A structural model. Tourism Management, 26(1), 45-56. https://doi.org/10.1016/j.tourman.2003.08.016

Žabkar, V., Brenčič, M. M., \& Dmitrović, T. (2010). Modelling perceived quality, visitor satisfaction and behavioural intentions at the destination level. Tourism Management, 31(4), 537-546. https://doi.org/10.1016/j.tourman.2009.06.005 